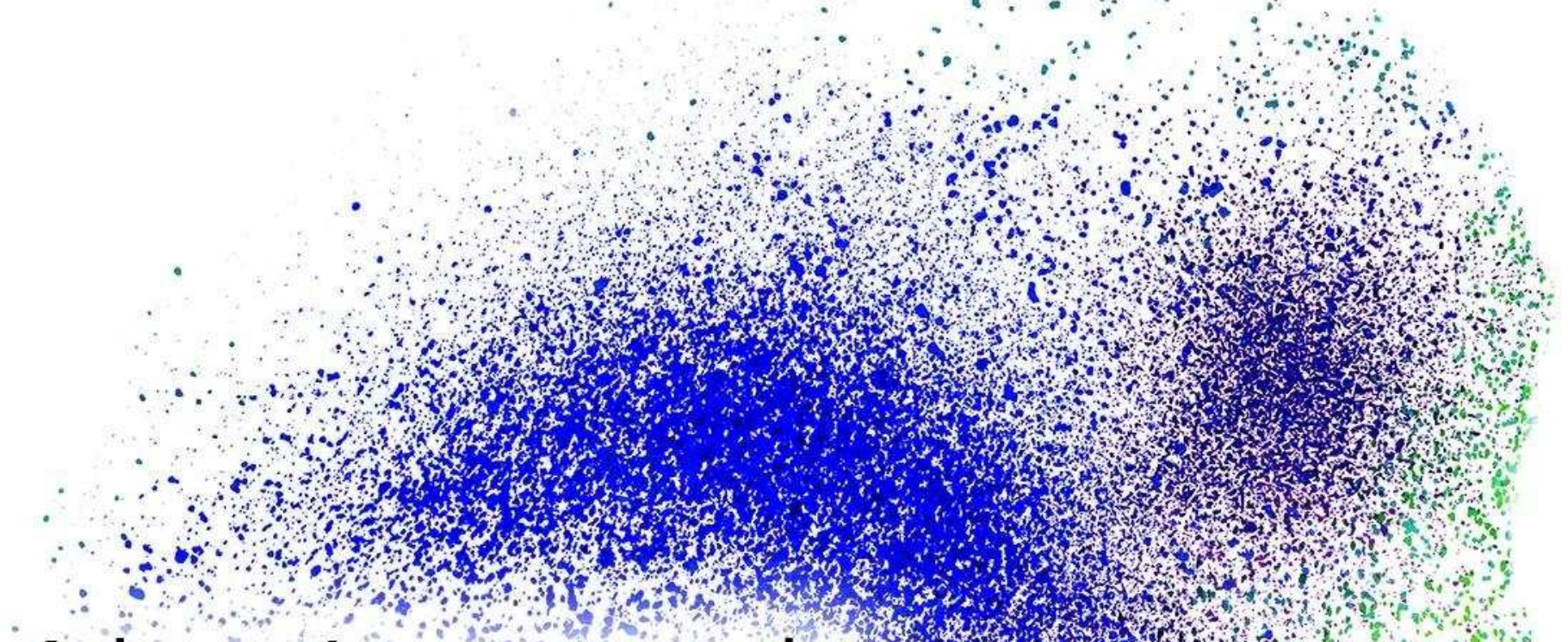

\title{
Advancing research:
}

\section{One cell at a time \\ One scientist at a time One discovery at a time}
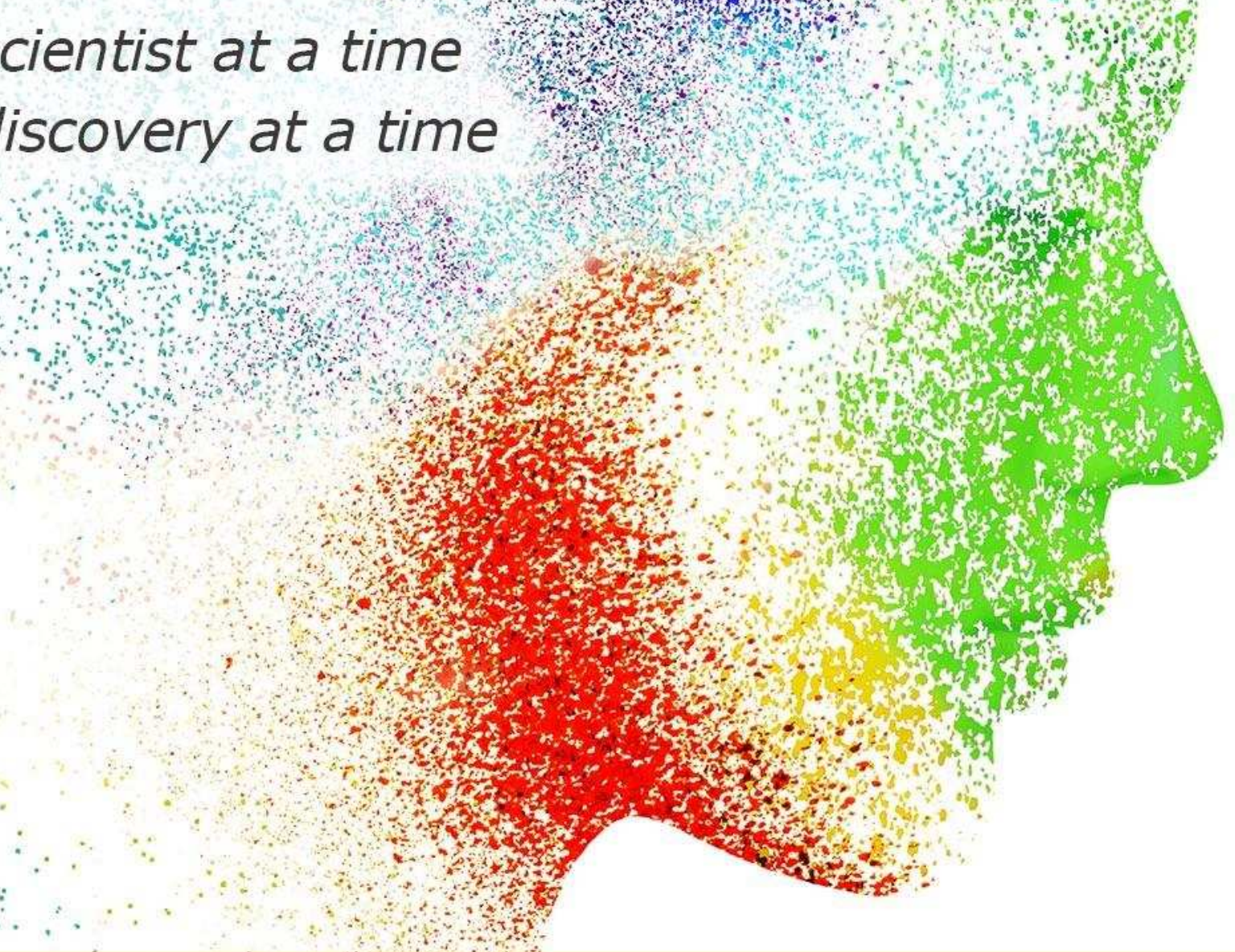

Proven solutions

that further science

BD Accuri ${ }^{\mathrm{TM}}$ C6 Plus

BD FACSCelesta ${ }^{\text {TM }}$

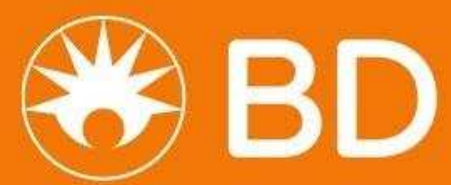

BD LSRFortessa ${ }^{\mathrm{TM}}$

Discover more> 


\title{
RECEPTORS FOR HORMONES AND GROWTH FACTORS AND (ONCO)-GENE AMPLIFICATION IN HUMAN OVARIAN CANCER
}

\author{
Els M.J.J. Berns ${ }^{1.3}$, Jan G.M. Klijn ${ }^{1}$, Sonja C. Henzen-Logmans ${ }^{2}$, Cees J. Rodenburg ${ }^{1}$, Maria E.L. van Der Burg ${ }^{1}$ and \\ John A. FOEKENS ${ }^{1}$ \\ 'Division of Endocrine Oncology (Department of Medical Oncology) and ${ }^{2}$ Department of Pathology, Dr. Daniel den Hoed Cancer \\ Center, P.O. Box 5201, 3008 AE Rotterdam, The Netherlands.
}

\begin{abstract}
Receptor status and gene amplification were studied in advanced human ovarian adenocarcinoma tissues, borderline and benign ovarian tumours and normal ovarian tissues. Sixtyfive percent $(53 / 82)$ of ovarian adenocarcinomas, $57 \%(8 / 14)$ of benign/borderline tumours and only $31 \%(5 / 16)$ of normal ovarian tissues studied showed specific 125|-EGF (epidermal growth factor) binding (median: 17; 10 ; and 0 fmol EGF-R/mg protein, respectively) and a significant increase in progesterone receptor (PgR) levels was observed in these groups (median: 5; 33; and $152 \mathrm{fmol} / \mathrm{mg}$ protein, respectively). No correlations were observed between the levels of EGF-R and the levels of either oestrogen receptors (ER) or PgR. All membrane samples of $\mathbf{2 5}$ adenocarcinomas studied by Scatchard analysis were positive for insulin-like growth-factor-I receptors (IGF-I-R) and contained higher IGF-I-R levels than membranes of 10 normal ovarian tissues, of which 9 were positive (median: 64 and 26 fmol IGF-I-R/mg membrane protein, respectively). Also, as measured by autoradiography, 37 adenocarcinoma tissues showed a higher expression of IGF-I-R $(1.5+$ to $4+)$ than sections derived from 10 normal ovarian tissues (I+). ${ }^{125}$ |-IGF-I binding was predominantly associated with epithelial tumour cells, the surrounding connective tissue was negative and in several samples high expression of IGF-I-R was found in areas of tumour necrosis. Southern blot analysis of DNAs isolated from 25 ovarian adenocarcinomas revealed no amplification of the IGF-I-R or the EGF-R gene. The HER2/neu gene was amplified only in 2 out of 3 histologically confirmed endometrioid adenocarcinomas studied but not in $\mathbf{2 2}$ other tumours. An amplification of the c-myc gene was observed in $28 \%(7 / 25)$ of the tumours. All c-myc-amplified tumours were PgR-negative. No rearrangement was observed for any of the genes studied. In conclusion, ovarian adenocarcinoma tissues show a decrease in $P g R$ levels and an increased expression of IGF-I-R and EGF-R, in the absence of gene amplification, when compared to benign/ borderline ovarian tumours and normal ovarian tissues. In addition, amplification of the c-myc and HER2/neu genes, without rearrangement of these genes, occurs in a minority of these tumours.

(1) 1992 Wiley-Liss, Inc.
\end{abstract}

Ovarian cancer is the leading cause of death from gynaecological cancers. Epidemiological studies show that there are relationships between the incidence of breast, endometrial and ovarian cancer. The vast majority of these female reproductive cancers are of epithelial and not of stromal origin. Steroid hormone receptors are found in the tumour cells of these malignancies (Slamon et al., 1989). Hormones and growth factors involved in menstrual activity are the likeliest candidates for the aetiology of female reproductive cancers. Analyses have shown that histologic grade, stage of the disease, ploidy and age of the patient appear to influence disease-free survival in ovarian cancer (Rao and Slotman, 1991). Nevertheless, additional (prognostic) factors in these cancers are needed to define the appropriate treatment for the individual patient. In recent years much attention has been focused on the role of growth factors and the activation of oncogenes in the development of human malignancies. Hormone receptor, growth-factor receptor and oncogene status appeared to be of importance with respect to clinical outcome of breast cancer (Foekens et al., 1991; Klijn et al., 1992; Berns et al., 1992). For instance, increased expression of epidermal growth factor receptor (EGF-R, c-erbB-1) was associated with poor progno- sis in primary breast tumours (Sainsbury et al., 1987). However, the role of the EGF-R as a prognostic factor in subgroups of breast cancer patients is still under debate (reviewed by Klijn $e t$ al., 1992). The c-erbB-2 gene (HER2 or neu), which shows extensive homology but is distinct from the c-erb $\mathrm{B}-1$ gene, was shown to be amplified or over-expressed in approximately $20 \%$ of human mammary tumours (reviewed by: Maguire and Greene, 1989). It was suggested that amplification of the c-erb $\mathrm{B}-2$ gene was a bad prognostic indicator in node-positive breast-cancer patients (Slamon et al., 1987), whereas amplification of another oncogene, $c-m y c$, may be of prognostic value for patients with node-negative or steroid-receptor-positive breast cancer (Berns et al., 1992). Data on another membranebound growth-factor receptor, the insulin-like growth factor-1 receptor, are scarce in human primary breast cancer (reviewed by Foekens et al., 1991). Studies on prognostic factors in ovarian cancer are limited. Data on EGF-R (c-erbB-1) expression and prognosis in ovarian cancer have been reported (Battaglia et al., 1989; Bauknecht et al., 1990; Berchuck et al., 1991). Amplification (Slamon et al., 1989) and over-expression (Berchuck et al., 1990) of $H E R 2 /$ neu/c-erbB-2 in primary tumours suggest a worse prognosis for patients with ovarian cancer. The role of $c-m y c$ amplification and IGF-1-R in ovarian cancer is, as yet, unclear.

The similarities between human breast and ovarian cancer prompted us to study the incidence and role of steroid hormones, growth factors, their receptors and oncogeneamplifications in ovarian carcinogenesis. We have studied the incidence and amount of IGF-1-R, using radioligand binding assays on membrane preparations and/or autoradiography on cryostat sections. The results were compared with those from non-epithelial ovarian tumours, benign and borderline malignancies and normal ovarian tissues. In addition, the incidences of EGF-R, ER and PgR and (onco-)gene amplification were assessed because these factors could be important in tumorigenesis and may eventually assist in a better discrimination between high-and low-risk ovarian cancer patients.

\section{MATERIAL AND METHODS}

Patients and tissues

Tissues of ovarian carcinomas, benign and borderline ovarian tumours and normal ovaries were collected between 1988 and 1989 in our cancer centre. Tissue samples were placed on ice immediately after excision, transported to the laboratory at a temperature below $-70^{\circ} \mathrm{C}$ and stored in liquid nitrogen or at $-70^{\circ} \mathrm{C}$. The mean age of the patients from whom normal ovarian tissue was obtained was 63 (range: $47-79$ ) and the mean age of the patients with ovarian tumours was 56 (range: 26 to 78). Following the WHO classification (1973) these carcinomas were subtyped into: serous $(n=44)$, mucinous (14), endometrioid (8), clear-cell (7), mixed (8) and poorly differentiated adenocarcinomas $(10)$. The remaining samples

${ }^{3}$ To whom correspondence and reprint requests should be sent. Fax: 011-31-104861058.

Received: March 24, 1992. 
were subtyped as adenomas of borderline malignancy (9), adenomas (5), adenofibroma (1), fibrothecomas (3), granulosa cell tumours (3) and malignant teratoma, intermediate type (MTI) (1).

\section{Receptor assays}

Tumour tissue (0.4-0.8 g) was ground and homogenized as recommended by the EORTC for processing of breast tumour tissue for cytosolic ER and PgR determinations (EORTC Breast Cancer Cooperative Group, 1980). The homogenate was centrifuged for $30 \mathrm{~min}$ at $100,000 \mathrm{~g}$ at $4^{\circ} \mathrm{C}$, and the supernatant fraction (cytosolic extract) was used for ER and PgR determinations, either with enzyme immunoassays (EREIA and PgR-EIA kits, Abbott, Abbott Park, IL) or with radioligand binding assays. The $\mathrm{ER}$ and $\mathrm{PgR}$ values shown are those obtained from the EIAs, after establishing that data obtained with the EIAs on cytosols from ovarian adenocarcinomas significantly correlated with those of the conventional biochemical assays (Spearman correlation: $\mathrm{Rs}=0.81$ for $\mathrm{ER}$ and $\mathrm{Rs}=0.89$ for $\mathrm{PgR}$, respectively; for both $2 p<0.001$, $n=31$ ). The membrane fraction for EGF-R and IGF-1-R determinations was obtained in the supernatant fraction after re-homogenization of the $100,000 \mathrm{~g}$ pellet in $2.5 \mathrm{ml} \mathrm{BBB}$-buffer (20 mM phosphate buffer $\mathrm{pH} 7.4$, containing $0.15 \mathrm{M} \mathrm{NaCl}$ and $70 \mu \mathrm{g} / \mathrm{ml}$ Bacitracin) on ice with 35 -sec bursts at $20,000 \mathrm{rpm}$ of an Omni-1000 tissue homogenizer (OMNI, Waterbury, CT). The homogenate was centrifuged for $10 \mathrm{~min}$ at $1,000 \mathrm{~g}$, and the supernatant was used as membrane preparation. After an aliquot had been taken for membrane-protein determination, $1.1 \%(\mathrm{w} / \mathrm{v})$ bovine serum albumin (BSA, purified, Behringwerke, Marburg, Germany) in BBB-buffer was added to a final concentration of $0.1 \%(\mathrm{w} / \mathrm{v})$ BSA. Aliquots $(100 \mu \mathrm{l})$ of cell membrane preparations were incubated with 8 concentrations (ranging from 0.15 to $3.5 \mathrm{nM}$ ) of ${ }^{125} \mathrm{I}-\mathrm{mEGF}$ tracer in a final volume of $140 \mu \mathrm{l}$ for $16 \mathrm{hr}$ at $20^{\circ} \mathrm{C}$. Non-specific binding was assessed in duplicate using $0.75 \mathrm{nM}{ }^{125} \mathrm{I}-\mathrm{mEGF}$ and a 250 -fold excess of non-labelled mEGF. Iodinated mEGF (specific activity $500-600 \mathrm{Ci} / \mathrm{mmol}$ ), prepared by Protag- 125 or Enzymobeads as described in detail by Kienhuis et al. (1991) was kindly provided by Dr. Th.J. Benraad (Sint Radboud Hospital, Nijmegen, The Netherlands). Separation of bound and free ligand was performed using hydroxylapatite (HAP) adsorption (Benraad and Foekens, 1990), with minor modifications. A membrane protein threshold of $0.2 \mathrm{mg} / \mathrm{ml}$ was adapted to avoid possible false-negative results. Scatchard analysis of specific ${ }^{125} \mathrm{I}-\mathrm{IGF}-1$ (S.A. $2000 \mathrm{Ci} / \mathrm{mmol}$ : human-Thr ${ }^{59}$-analog, Amersham, Aylesbury, UK) binding was performed after separation of bound and free ligand by high-speed centrifugation as described previously (Foekens et al., 1989).

\section{Autoradiography}

Frozen tissue sections $(5 \mu \mathrm{m})$ originating from 37 human ovarian carcinomas and 9 normal ovaries were stored at $-70^{\circ} \mathrm{C}$ for up to 5 days. Prior to the assay, the slides were brought to room temperature and pre-incubated for $10 \mathrm{~min}$ in a PBS solution containing Bacitracin $(40 \mu \mathrm{g} / \mathrm{ml})$ and BSA $(0.5 \%)$; BBB-buffer.

For IGF-1 receptor autoradiography, the cryostat sections were incubated with BBB-buffer containing $100 \mathrm{pM}^{125} \mathrm{I}-\mathrm{IGF}-1$ with or without a 1,000 -fold molar excess of unlabeled IGF-1 for $2 \mathrm{hr}$ at room temperature. After incubation, the sections were washed 4 times with BBB buffer and subsequently dipped in water and acetone. The sections were air-dried at room temperature and placed against Hyperfilm ${ }^{3} \mathrm{H}$ (Amersham). Slides were exposed for 3 days and the Hyperfilm was processed according to the manufacturer's instructions.

Slides were scored as $1+$ (indicating weak specific receptor presence) to $4+$ (indicating strong specific receptor presence). Sections of one of a few breast tumour specimens, which were negative for IGF-1 receptors in Scatchard plot analysis of membrane preparations (15/214: 7\%, Foekens et al., 1989), were used as a negative control. Human placenta was used as a positive control tissue.

\section{DNA analysis}

DNA was isolated from an aliquot of the total tissue homogenate. Southern blotting of EcoR1-digested DNA was performed by standard techniques (Berns et al., 1992). In brief, digested DNA was size-fractionated on a $0.6 \%$ agarose gel and transferred to a nylon membrane (Hybond N Plus, Amersham) and hybridized overnight at $65^{\circ} \mathrm{C}$ with randomly primed, ${ }^{32} \mathrm{P}-\mathrm{dATP}$-labelled probes (specific activity of $1-2 \times 10^{4} \mathrm{cpm} / \mu \mathrm{g}$ DNA). EGF-R (EGF receptor probe pHER-A 64-1), HER2/ neu (pHER2-436-1, ATCC 59296); c-myc, an EcoR1-Clal human exon 3-specific c-myc; and IGF-1-R (pIGF-9-R.8, ATCC 59295) were obtained from ATCC (Rockville, MD). After washing at high stringency $(0.3 \times \mathrm{SSC})$, autoradiography with intensifying screens was performed for $1-2$ days at $-70^{\circ} \mathrm{C}$ using Kodak XAR-5 films, and autoradiograms were scanned with a Bio-Rad (Richmond, CA) Video densitometer 620. The IGF-1-R probe was used as a control ( 2 gene copies) for densitometry and for the amount of DNA immobilized on the membrane. In our recent experience (Berns et al., 1992) concerning measurement of c-myc and HER2/neu amplification in 975 breast tumours, the incidence for c-myc amplification was $17 \%$ and that of $H E R 2 / n e u$ amplification was $19 \%$ (these percentages are similar to average percentage values, reported by others).

\section{Statistics}

Associations between groups to be compared were assessed by the Spearman rank correlation test. Differences between groups were tested non-parametrically by the Wilcoxon 2-sample test (Mann-Whitney U-test).

\section{IGF-1-R autoradiography}

RESULTS

In all samples, positivity for specific ${ }^{125}$ I-IGF-1 binding was observed by IGF-1-R receptor autoradiography. Tissue sections derived from ovarian adenocarcinomas showed increased density of IGF-1-R $(1.5+$ to $4+, \mathrm{n}=37)$ when compared to normal ovarian tissues $(1+, n=10)$. In tumours, high density of IGF-1-R was exclusively associated with epithelial tumour cells, while surrounding connective tissue was devoid of specific ${ }^{125} \mathrm{I}-\mathrm{IGF}-1$ binding. Examples of autoradiograms of 2 tumour tissues with stromal tissue are shown in Figure 1.

In $71 \%(5 / 7)$ of the tumours with necrotic areas (7/37), high expression of IGF-1-R was observed in these necrotic areas, whereas in 2 tumours necrotic areas were negative for specific ${ }^{125}$ I-IGF-1 binding. An example of ${ }^{125} \mathrm{I}-\mathrm{IGF}-1$ binding in a necrotic area, with histology, is shown in Figure 2.

\section{EGF-R, IGF-1-R, ER and PgR Scatchard-analysis}

The combined EGF-R and IGF-1-R receptor data with respect to median (+ range) and maximum binding capacities and apparent dissociation constants of the various tissue biopsies analyzed are listed in Table I. Fifty-three of the 82 adenocarcinomas studied $(65 \%)$ were positive for EGF-R by Scatchard analysis, with a median level of $17 \mathrm{fmol} / \mathrm{mg}$ protein. The group of adenocarcinomas was composed of 6 subgroups with different histological classifications, and with respect to EGF-R levels, there were no significant differences between these various subgroups (Fig. $3 a$ ). In the combined group of benign tumours ( 5 cystadenomas, 1 adenofibroma) and borderline malignancies, $57 \%(8 / 14)$ and, in the normal ovarian tissues, only $31 \%(5 / 16)$ were positive for EGF-R. There was a near-significant difference $(2 p=0.06)$ between the EGF-R levels in adenocarcinomas and normal ovaries. Epithelial ovarian tumours might be expected to contain a higher 

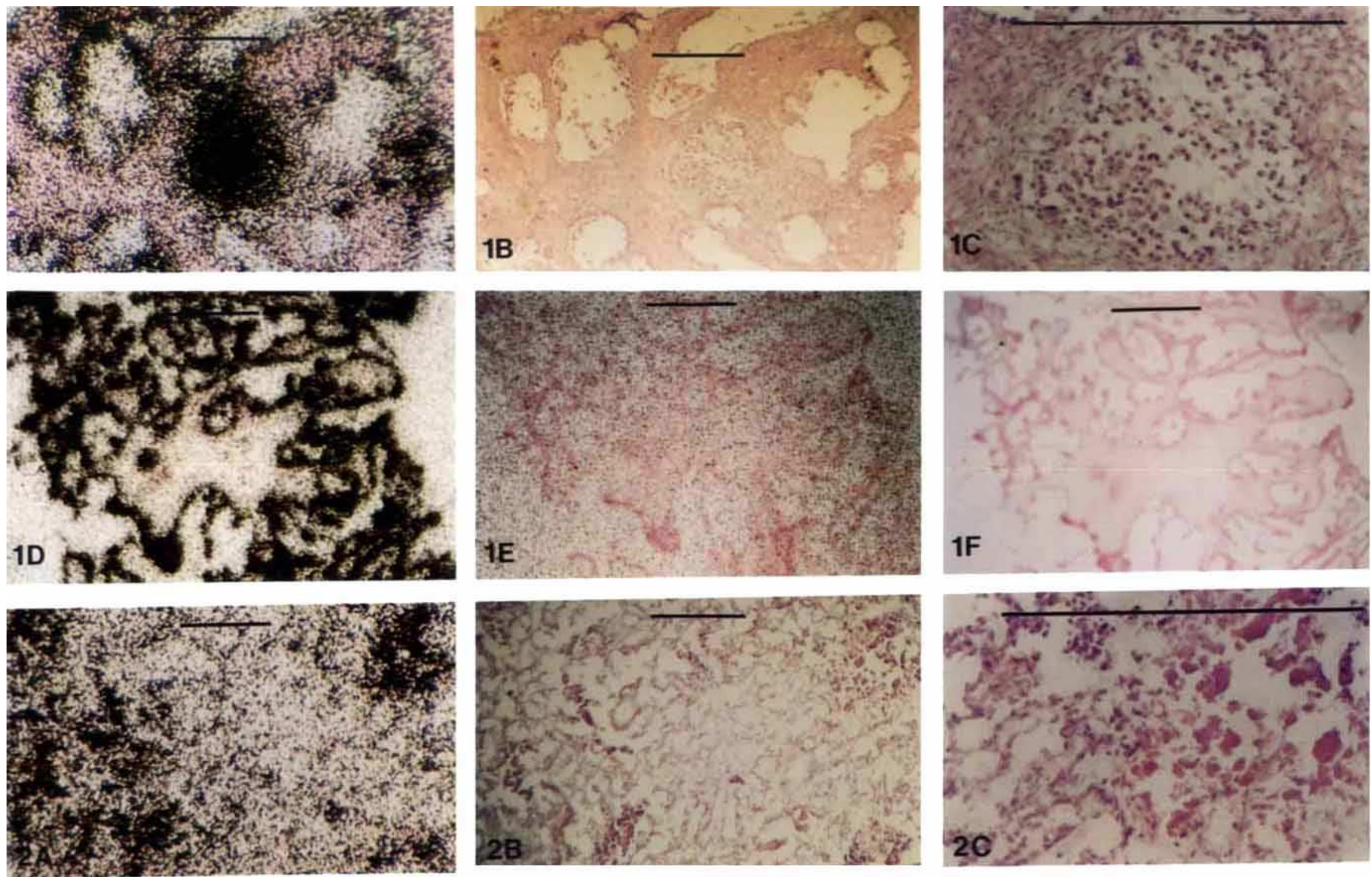

FIGURE 1 - Autoradiographic localization of ${ }^{125}$ I-IGF-1 receptors in ovarian cancer. (a and $d$ ) Total binding; cryostat sections were incubated for $2 \mathrm{hr}$ at room temperature with i2i-I-IGF-1. Autoradiograms show high density of labeling of epithelial tumour cells and low density of labeling on surrounding tissue. ( $b$ and $f$ ) Haematoxylin-stained sections showing tumour tissue. (c) A higher magnification of the central part of the tissue in $(b)$. (e) Non-specific binding, in semi-adjacent section of tumour shown in $(d)$.

FIGURE 2 - Autoradiographic localization of 125 -IGF-1 receptors in necrotic ovarian tissue. (a) Total binding cryostat sections were incubated for $2 \mathrm{hr}$ at room temperature with 125. I-IGF-1; autoradiogram shows high density of labeling of necrotic area. (b) Haematoxylinstained section showing necrotic area from $(a)$. (c) Higher magnification of the upper right part of $(b)$ 
TABLE I - AMOUNTS OF ER, PgR, EGF-R, IGF-1-R, IN DIFFERENT OVARIAN TISSUES, AND DISSOCIATION CONSTANTS OF EGF AND IGF-1 BINDING

\begin{tabular}{|c|c|c|c|c|}
\hline Receptor type & Adeno-ca & Benign + borderline & Normal & Others \\
\hline 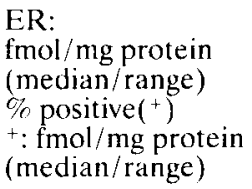 & $\begin{array}{l}19(0-162) \\
(\mathrm{n}=91) \\
60 \% \\
60(11-162) \\
(\mathrm{n}=55)\end{array}$ & $\begin{array}{l}6(0-52) \\
(\mathrm{n}=15) \\
47 \% \\
25(14-52) \\
(\mathrm{n}=7)\end{array}$ & $\begin{array}{l}10(0-66) \\
(n=19) \\
53 \% \\
24(10-66) \\
(n=10)\end{array}$ & $\begin{array}{l}0(0-19) \\
(n=7) \\
29 \% \\
19(11+19) \\
(n=2)\end{array}$ \\
\hline $\begin{array}{l}\text { PgR: } \\
\text { fmol/mg protein } \\
\text { (median/range) } \\
\% \text { positive }\left(^{+} \text {) }\right. \\
+: \text { fmol/mg protein } \\
\text { (median/range) }\end{array}$ & $\begin{array}{l}5(0-592) \\
(\mathrm{n}==90) \\
38 \% \\
35(11-592) \\
(\mathrm{n}=34)\end{array}$ & $\begin{array}{l}33(0-366) \\
(n=15) \\
73 \% \\
83(15-366) \\
(n=11)\end{array}$ & $\begin{array}{l}152(0-310) \\
(n=19) \\
89 \% \\
160(38-310) \\
(n=16)\end{array}$ & $\begin{array}{l}16(0-105) \\
(n=7) \\
57 \% \\
101(16-105) \\
(n=4)\end{array}$ \\
\hline $\begin{array}{l}\text { EGF-R:B } \\
\text { fmol/mg protein } \\
\text { (median/range) } \\
\% \text { positive }\left({ }^{+}\right) \\
+: \text {fmol/mg protein } \\
\text { (median/range) }\end{array}$ & $\begin{array}{l}17(0-158) \\
(\mathrm{n}==82) \\
65 \% \\
24(5-158) \\
(\mathrm{n}=53)\end{array}$ & $\begin{array}{l}10(0-37) \\
(n=14) \\
57 \% \\
33(6-37) \\
(n=8)\end{array}$ & $\begin{array}{l}0(0-50) \\
(\mathrm{n}=16) \\
31 \% \\
39(13-50) \\
(\mathrm{n}=5)\end{array}$ & $\begin{array}{l}58(55-62) \\
(\mathrm{n}=4) \\
100 \% \\
\text { same as above }\end{array}$ \\
\hline $\begin{array}{l}\mathrm{EGF}-\mathrm{R}: \mathrm{K}_{\mathrm{D}} \\
\mathrm{nM} \\
(\mathrm{median} / \text { range }) \\
\mathrm{nM} \\
(\text { mean } \pm \mathrm{SD})\end{array}$ & $\begin{array}{l}0.9(0.3-1.6) \\
(n=53) \\
0.9 \pm 0.3\end{array}$ & $\begin{array}{l}0.6(0.3-1.0) \\
(n=8) \\
0.6 \pm 0.2\end{array}$ & $\begin{array}{l}1.1(0.3-1.4) \\
(n=5) \\
1.0 \pm 0.4\end{array}$ & $\begin{array}{l}1(1.0-1.1) \\
(n=4) \\
1.0 \pm 0.1\end{array}$ \\
\hline $\begin{array}{l}\text { IGF-R:B } \text { max }_{\text {fmol/mg protein }} \\
\text { (median/range) } \\
\text { c/ positive }\left(^{+} \text {) }\right. \\
+: \text { fmol/mg protein } \\
\text { (median/range) }\end{array}$ & $\begin{array}{l}64(6-220) \\
(\mathrm{n}=25) \\
100 \% \\
\text { same as above }\end{array}$ & $\begin{array}{l}30(9-36) \\
(\mathrm{n}=5) \\
100 \% \\
\text { same as above }\end{array}$ & $\begin{array}{l}26(0-61) \\
(n=10) \\
90 \% \\
26(15-61) \\
(n=9)\end{array}$ & $\begin{array}{l}88(0-113) \\
(n=5) \\
80 \% \\
113(36-113) \\
(n=4)\end{array}$ \\
\hline $\begin{array}{l}\text { IGF-R: } \mathrm{K}_{\mathrm{D}} \\
\mathrm{nM} \\
\text { (median/range) } \\
\mathrm{nM}\end{array}$ & $\begin{array}{l}0.29(0.11-0.78) \\
(\mathrm{n}=25) \\
0.34 \pm 0.17\end{array}$ & $\begin{array}{l}0.17(0.12-0.41) \\
(\mathrm{n}=5) \\
0.21 \pm 0.12\end{array}$ & $\begin{array}{l}0.49(0.12-0.82) \\
(\mathrm{n}=9) \\
0.45 \pm 0.22\end{array}$ & $\begin{array}{l}0.3(0.25-0.39) \\
(\mathrm{n}=4) \\
0.31 \pm 0.06\end{array}$ \\
\hline
\end{tabular}

EGF- and IGF-1-receptor assays were performed with Scatchard analysis as described in the text. ER and PgR were measured by enzyme immunoassays. Composition of the various groups with respect to different histologically-confirmed subclasses is described in the "Patients" section. ${ }^{+}$: indicates median content and range, given for receptor-positive tumours only.

percentage of epithelial cells than normal ovaries. Therefore, it should be realized that the differences in EGF-R levels described may be biased. Four non-epithelial ovarian tumours (2 granulosa-cell tumours, 1 fibrothecoma and $1 \mathrm{MTI}$ ) contained high levels of EGF-R, with a median of $58 \mathrm{fmol} / \mathrm{mg}$ protein.

For IGF-1-R (Table I), higher levels of IGF-1-R were measured in membrane preparations of adenocarcinomas than in those of the combined group of benign tumours and borderline malignancies or those of normal ovarian tissues. However, in contrast to what was observed for EGF-R, all adenocarcinoma and all combined benign/borderline samples analyzed were positive for IGF-1-R by Scatchard analysis. Nine out of $10(90 \%)$ of the normal ovarian tissues were positive for IGF-1-R. Four out of 5 non-epithelial ovarian tumours (2 granulosa-cell tumours, 2 fibrothecomas and 1 MTI) contained very high levels (median $88 \mathrm{fmol} / \mathrm{mg}$ protein) of IGF-1-R. In agreement with the results of autoradiography on frozen sections, the IGF-1-R levels, measured by Scatchard analysis, were higher in adenocarcinomas than in normal ovarian tissues (median $64 \mathrm{vs} .26 \mathrm{fmol} / \mathrm{mg}$ protein). Like the ${ }^{125} \mathrm{I}-\mathrm{EGF}$ binding in the various groups, the affinity $\left(\mathrm{K}_{\mathrm{D}}\right)$ of ${ }_{125} \mathrm{I}-\mathrm{IGF}-\mathrm{l}$ for its receptor in the different tissues analyzed was not different (Table I).

Cytosolic ER and PgR data are given in Table I. Sixty percent of the adenocarcinoma tissues $(55 / 91)$ were positive for ER ( $\geq 10 \mathrm{fmol} / \mathrm{mg}$ protein), with a median level of 19 $\mathrm{fmol} / \mathrm{mg}$ protein. In the combined group of benign/borderline tumours $47 \%$ and among the normal ovarian tissues $53 \%$ were
ER-positive. Only $29 \%$ of the non-epithelial ovarian tissues (2 out of 7) were ER-positive. The ER levels were not significantly different when adenocarcinomas were compared with either benign/borderline tumours or normal ovarian tissue. However, ER levels were higher in serous than in mucinous adenocarcinomas $(2 p=0.001$; Fig. $3 b)$. When the ER levels of serous or mucinous adenocarcinomas were compared with the combined group of other adenocarcinomas, there was a near-significant lower or higher level, respectively, in the latter group of tumours (serous vs. others, $2 p=0.06$ and mucinous vs. others, $2 p=0.07$ ).

Thirty-eight percent (34/90) of the adenocarcinomas tissues were positive for $\mathrm{PgR}$ ( $\geq 10 \mathrm{fmol} / \mathrm{mg}$ protein). Of the benign/ borderline tumours $73 \%$ and of the normal tissues $89 \%$ were positive. Most pronounced was the observed difference in the median of the measured PgR levels, decreasing from $152 \mathrm{fmol}$ $\mathrm{mg} /$ protein in normal tissues, via $33 \mathrm{fmol} / \mathrm{mg}$ protein in benign/borderline tissues, to $5 \mathrm{fmol} / \mathrm{mg}$ protein in adenocarcinomas (Table I). These differences were significant for all groups studied (adenocarcinomas $v s$. benign/borderline, $2 p=0.0012$; adenocarcinomas $v s$. normal ovaries, $2 p<0.0001$ and benign/borderline $v$ s. normal ovaries, $2 p=0.018$ ). The levels of $\mathrm{PgR}$ in the 6 histologic subgroups of adenocarcinomas did not differ (Fig. $3 c$ ).

In addition, for these adenocarcinoma samples, Spearman regression analysis did not reveal a significant correlation between the levels of EGF-R and ER and of EGF-R and PgR values, whereas there was a weak positive relationship 

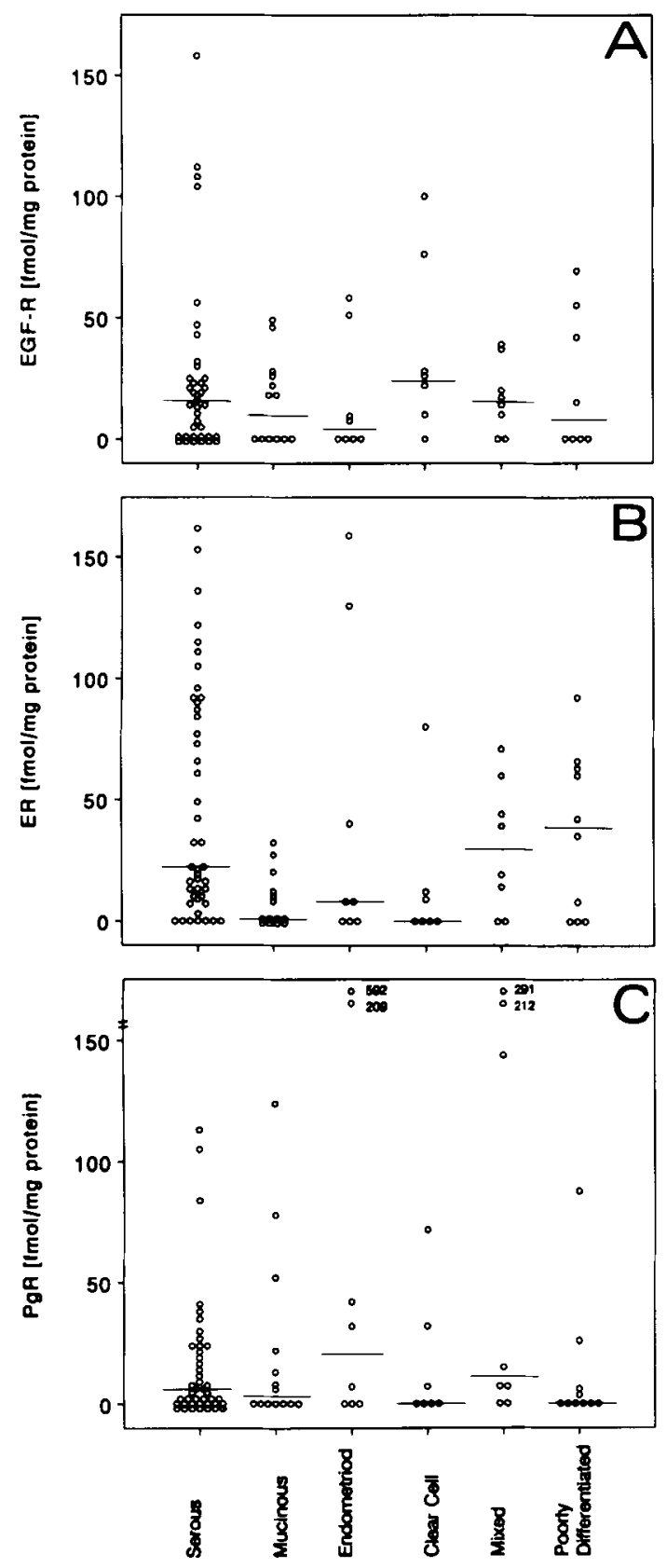

Figure 3 - Levels of EGF-R $(a)$, ER $(b)$ and PgR $(c)$ in 6 histological subgroups of ovarian adenocarcinomas. Horizontal line indicates the median value of the respective receptors.

( $R s=0.25, n=90 ; 2 p<0.05)$ between the levels of $E R$ and PgR.

\section{Gene amplification}

Twenty-five different DNA samples isolated from adenocarcinoma tissues (14 serous, 4 mucinous, 3 endometrioid, 1 clear-cell, and 3 mixed tumours) were analysed by Southern blotting for amplification or rearrangement of the EGF-R, IGF-1-R, c-myc, and HER2/neu genes. No rearrangement for any of the genes studied in EcoR1-digested DNAs was observed. No amplification (more than 2 gene copies) of the EGF-R and IGF-R gene was noted (Fig. 4). Amplification of

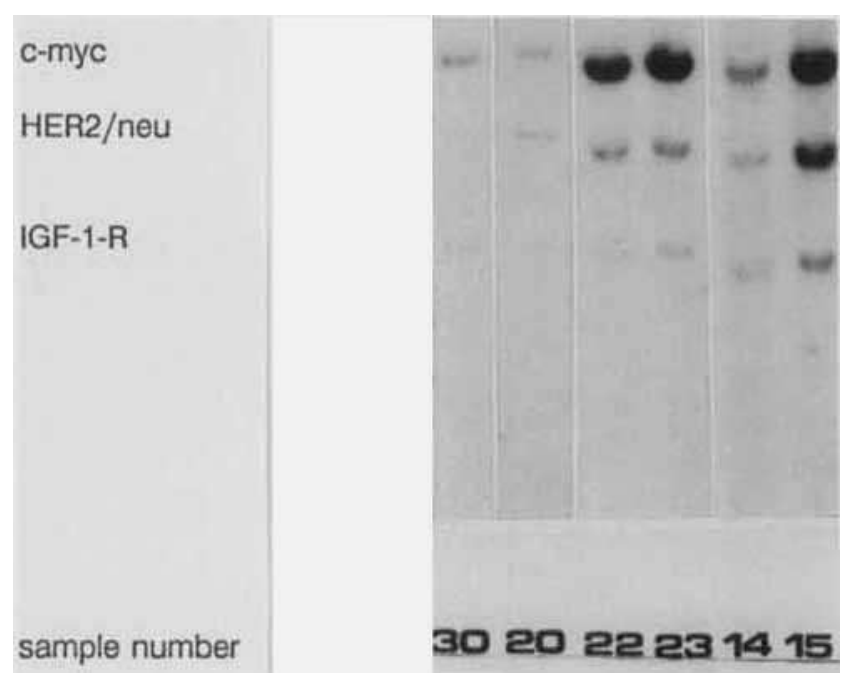

Figure 4 - Southern blot of DNA from ovarian adenocarcinoma tissue samples. Total DNA was digested with EcoR1, subjected to electrophoresis, transferred to a nylon membrane and hybridized with c-myc, HER2/neu and IGF-1-R simultaneously. Filters were washed at high stringency and exposed for 2 days, as described in the text. In lanes 22,23 and 15 amplified oncogenes are shown.

the c-myc gene was found in DNAs from 7 (28\%) adenocarcinomas. The tumours which contained an amplified c-myc gene were all negative for cytosolic $\mathrm{PgR}$, whereas 5 of these tumours were positive for ER. The c-myc amplifications were found in 1 mucinous ( 10 copies), 1 endometrioid ( 10 copies), 1 mixed ( 10 copies), and 4 serous tumours $(1 \times 10$ and $3 \times 5$ copies $)$. $H E R 2 /$ neu amplifications were only observed in DNA samples isolated from 2 (5 and 10 copies) of the 3 histologically confirmed endometrioid tumours studied. The other 22 samples analysed contained diploid amounts of the $H E R 2 / n e u$ gene. Figure 4 shows an example of an autoradiogram of EcoR1-digested DNAs probed with a mixture of c-myc, HER2/ netu and IGF-1-R probes. One of the 3 mucinous samples analysed showed a co-amplification of the c-myc and HER2/ neu genes.

\section{DISCUSSION}

We have shown that the levels of EGF-R, IGF-1-R, ER, $\mathrm{PgR}$ and gene copy numbers of $H E R 2 /$ neu and c-myc vary in ovarian adenocarcinoma, benign/borderline malignancies and normal ovarian tissuc.

The median levels of IGF-1-R and ER are approximately twice as high in ovarian adenocarcinoma as in normal ovarian tissue. In contrast, the median level of $\mathrm{PgR}$ was about 30 times lower in ovarian adenocarcinoma than in normal ovarian tissue. The frequency of receptor positivity for ER and IGF-1-R was similar in normal, benign/borderline and adenocarcinoma tissues. On the other hand, EGF-R levels were increased (from $31 \%$ to $57 \%$ to $65 \%$, respectively), and $\mathrm{PgR}$ levels were decreased (from $89 \%$ to $73 \%$ to $38 \%$, respectively). The few cases of non-epithelial tumours studied showed high levels of both EGF-R and IGF-1-R, with low levels of ER and $\mathrm{PgR}$. In breast cancer, higher levels and incidence of IGF-1-R when compared to benign and normal breast tissue have also been reported (Pekonen et al., 1988; Peyrat et al., 1988). Our autoradiographical analyses revealed that the increased amounts of IGF-1-R are mainly associated with epithelial tumour cells of the ovarian adenocarcinomas, and sometimes 
with necrosis. The (biological) significance of specific ${ }^{125} \mathrm{I}-$ IGF-1 binding to these necrotic areas is not clear. It may indicate rapidly growing tumours with insufficient vascularization. In human breast-cancer tissues, specific ${ }^{125}$ I-EGF binding has also been observed in necrotic areas by in vitro autoradiography (Reubi and Torhorst, 1988). This specific binding of growth factors in necrotic tissue indicates the need for histological examination of growth-factor binding and could be useful in predicting a possible heterogeneity of responses of the patient to (future) growth-factor antagonist therapy and/or growth-factor/growth-factor-receptor blocking therapy.

Like Bauknecht et al. (1990) and Zhang et al. (1989), we also observed that the EGF-R gene is not frequently amplified in ovarian tissues. Since the IGF-1-R gene is also not amplified, we conclude that amplification of these genes is not involved in ovarian carcinogenesis. However, amplification $(20-26 \%)$ of the $H E R 2 /$ neu gene (another member of the erb $\mathrm{B}$ family) has been reported in ovarian cancer by Zhang et al. (1989) and Slamon et al. (1989), but we (like Zhou et al., 1988) observed in only 2 cases $(8 \%)$ an amplification of the $H E R 2 /$ neu gene, each time in endometrioid adenocarcinomas. This suggests that routine analysis of $H E R 2 / n e u$ amplification in all ovarian adenocarcinomas may be clinically irrelevant but on the other hand the prognostic significance of $H E R 2 /$ neu amplification is still unclear.

Amplification of another important oncogene, the c-nyc gene, was observed in 7 out of 25 adenocarcinoma-DNAs $(28 \%)$ studied. This incidence is similar to that observed by Zhou et al. (1988) and Baker et al. (1990), 25\% and $29 \%$ amplification respectively, whereas in contrast Smith et al. (1989) did not find any amplification in their study. The c-myc amplifications described in our study may be associated with PgR-negativity, since all 7 tumours with an amplified c-myc gene were negative for cytosolic PgR, in spite of ER-positivity in 5 of these 7 cases. Similar results were described for breast cancer, where c-myc amplification was also found to be strongly associated with absence of the progesterone receptor (Berns et al., 1992).

Although there are similarities between breast and ovarian cancer (as described above), the present data show that there are differences as well. In the total group of ovarian adenocarcinomas, we found no negative relationship between EGF-R and $\mathrm{ER}$ or PgR (established by Spearman regression analysis) as observed in breast cancer. This is puzzling, since there is a large body of literature showing a negative relationship between EGF-R and ER or PgR in human breast-tumour biopsies (Klijn et al., 1992). Also as a prognosticator of survival and response to endocrine therapy, there is a disparity regarding the presence of prognostic significance of ER in breast cancer, and the absence of prognostic value of ER in ovarian cancer (Rao and Slotman, 1991). On the other hand, the levels of the oestrogen-regulated PgR appear to be of prognostic value in both ovarian carcinoma (Rao and Slotman, 1991) and breast cancer (Foekens et al., 1991). From these data we suggest that the role of the oestrogen receptor may be different in ovarian and in breast cancer. In ovarian cancer chromosome $6 \mathrm{q}$, the locus of the ER is often affected (Zheng et al., 1991). Furthermore, the expression of $\mathrm{pS} 2$, an oestrogen-regulated protein in breast cancer, is negative or low in ovarian cancers as measured by immuno-radiometric assays for pS2 (Foekens et al., 1990). Moreover, mRNA expression of $\mathrm{pS} 2$ appeared to be poorly correlated with ER in ovarian carcinomas (Wysocki et al., 1990). It would therefore be of interest to study the expression of other ER-regulated genes, like cathepsin D, in ovarian cancer, to obtain more insight into ovarian carcinogenesis and biology. Indeed, in a recent report (Scambia et al., 1991) it was suggested that cathepsin D was not correlated with ER expression.

The determination of possible prognostic or therapeutic significance of gene amplification or over-expression and growth-factor receptors (EGF-R) in ovarian cancer, as described by Bauknecht et al. (1990), is currently under investigation.

\section{ACKNOWLEDGEMENTS}

The authors thank the pathologists from all collaborative pathology departments (Zuider Hospital, Rotterdam; Dijkzicht Academic Hospital, Rotterdam; St. Clara Hospital, Rotterdam; Bergweg Hospital, Rotterdam; PATHAN, Rotterdam; Maria Hospital, Tilburg; and Bergen op Zoom) who generously provided ovarian (tumour) tissues. They also thank Mrs. I. van Staveren, Mr. H. Portengen, Mrs. E. Noordegraaf and Mrs. E. Fieret for expert technical assistance. This work was supported by the Dutch Cancer Society, NKB (Grants: DDHK 88-9 and 90-5).

\section{REFERENCES}

Battaglia, F.. Scambia. G., Panici. P.B., Bajocchi, G., Perrone. L., IACOBELl., S. and MANCUSO, S., Epidermal growth factor receptor expression in gynaecological malignancies. Gynecol. obstet. Invest., 27, 42-44 (1989).

BAUKNECHT, T., BIRMELIN, G., and Kommoss. F., Clinical significance of oncogenes and growth factors in ovarian carcinomas. J. ster. Biochem. mol. Biol., 37, 855-863 (1990).

Baker. V.V., Borst, P., Dixon, D., Hatch, H.D., Shingleton, M.M. and Miller. c-Myc amplification in ovarian cancer. Gynecol. Oncol., 38, 340-342 (1990).

BenRaAd, Th.J. and FoEkins, J.A., Hydroxylapatite assay to measure epidermal growth factor receptor in human primary breast tumors. Ann. clin. Biochem., 27, 272-273(1990).

Berchule, A., Kamel, A., Whitaker, R., Kerns, B., Olt, G., Kinney, R., Soper, J.T., Dodge, R., Clarke-Plearse, D.L., Marks, P., Mr.Kenzit, S., Yin, S. and BAST, R.C., JR., Overexpression of HER2/neu is associated with poor survival in advanced epithelial ovarian cancer. Cancer Re's. 50, 4087-4091 (1990).

Berchuck, A., Rodriguez, G.C., Kamel, A., Dodge, R.K., Soper, J.T., Clarke-PtearSE, D.L. and BAST, R.C., JR., EGF-R expression in normal ovarian epithelium and ovarian cancer. 1. Correlation of receptor expression with prognostic factors in patients with ovarian cancer. Amer. J. Obstet. Gunecol., 164, 669-674 (1991).

Berns, E.M.J.J., Klijn, J G.M., van Staveren, I.L., Portengen, H.,
Noordegraaf, E. and Foekens, J.A., Prevalence of amplification of the oncogenes $c$-myc, HER2/neu, and int-2 in a thousand human breast tumours: correlation with steroid receptor. Europ. J. Cancer, 28 , 697-700 (1992).

EORTC BREAST CANCER COOPERATIVE Group, Revision of the standards for the assessment of hormone receptors in human breast cancer. Europ. J. Cancer, 16, 1513-1515 (1980).

Foekens, J.A., Peters, H.A., Portengen, H., Noordegraaf, E., BERNS, E.M.J.J. and KLIJN, J.G.M., Cell biological prognostic factors in breast cancer: a review.J. clin. Immunoassay, 14, 184-195 (1991).

Foekens, J.A., Portengen, H., van Putten, W.J.L., Trapman, A.M.A.C., ReUbi, J-C., Alexieva-FigusCh, J. and Kl.IJN, J.G.M., Prognostic value of receptors for insulin-like growth factor-1, somatostatin, and epidermal growth factor in human breast cancer. Cancer Res., 49, 7002-7009 (1989).

Foekens, J.A., van Putten, W.L.J., Portengen, H., Rodenburg, C.J., Reubi, J-C., Berns, P.M.J.J., Henzen-Logmans, S., van der Burg, M.E.L., Alexieva-Figusch, J. and Klijn, J.G.M., Prognostic value of $\mathrm{pS} 2$ protein and receptors for epidermal growth factor (EGF-R), insulin-like growth factor-1 (IGF-1-R), and somatostatin (SS-R) in patients with breast and ovarian cancer. J. ster. Biochem. mol. Biol., 37, 815-821 (1990).

Kienhuis, C.B.M., Heuvel. J.J.T.M., Ross, H.A., Swinkels, L.M.J.W., FoEkENS, J.A. and BENRAAD, Th.J., Six methods for direct radioiodination of mouse epidermal growth factor compared: effect of non- 
equivalence in binding behaviour between labeled and unlabeled ligand. Clin. Chem., 37, 1749-1755 (1991).

Klijn, J.G.M., Berns, P.M.J.J., Schmitz, P.I.M. and Foekens, J.A., The clinical significance of epidermal growth factor receptor (EGF-R) in human breast cancer: a review on 5,232 patients. Endocr. Rev., 13, 3-17 (1992).

Maguire, H.C. and Greene, M.I., The neu(c-erbB-2) oncogene. Semin. Oncol., 16, 148-155 (1989).

Pekonen, F., Partanen, S., Mäkinen, T. and Rutanen, E-M., Receptors for epidermal growth factor and insulin-like growth factor 1 and their relation to steroid receptors in human breast cancer. Cancer Res., 48, 1343-1347 (1988).

Peyrat, J-P., Bonneterre, J., Beuscart, R., Dilane, J. and DeMAILLE, A., Insulin-like growth factor-1 receptors in human breast cancer and their relation to estradiol and progesterone receptors. Cancer Res., 48, 6429-6433 (1988).

RAO, B.R. and SLOTMAN, B.J., Endocrine factors in common epithelial ovarian cancer. Endocr. Rev., 12, 14-26 (1991).

REUBI, J-C. and TORHORST. J., EGF receptors in human breast cancer on viable and necrotic tumour cells. Breast Cancer Res. Treat., 12, 245-246 (1988).

Sainsbury, J.R.C., Farndon, J.R., Needham, G.K., Malcolm, A.J. and HARRIS, A.L.. Epidermal-growth-factor receptor status as predictor of early recurrence of and death from breast cancer. Lancet, II, 1398-1402 (1987)

Scambia, G., Benedetti, P., Ferrandina, G., Battaglia, F., BalocCHI, G. and MANCuSO, S., Cathepsin D assay in ovarian cancer: correlation with pathological features and receptors for oestrogen. progesterone and epidermal growth factor. Brit. J. Cancer, 64, 182-184 (1991).

Slamon, D.J., Clark, G.M., Wong, S.G., Levin, W.J., Ullrich, A. and MCGUIRE, W.L., Human breast cancer: correlation of relapse and survival with amplification of the HER2/neu oncogene. Science, 235, 177-182 (1987).

Slamon, D.J., Godolphin, W. and Jones, L.A., Studies of the HER2/neu proto-oncogene in human breast and ovarian cancer. Science, 244, 707-712 (1989).

Smith, D.M., Groff, D.E., Pokul, R.K., Bear, J.L. and Delgado, S., Determination of cellular oncogene rearrangement or amplification in ovarian adenocarcinomas. Am. J. Obstet. Gynecol., 161, 911-915 (1989).

Wysocki, S.J., Hahnel, E., Masters, A., Smith, V., McCartney, K. and HAHNEL, R., Detection of pS2 messenger RNA in gynecological cancers. Cancer Res., 50, 1800-1802 (1990)

Zhang, X., Silva, E., Gershenson, D. and Hung, M-C., Amplification and rearrangement of $c$-erbB protooncogenes in carcinoma of human female genital tract. Oncogene, 4, 985-989 (1989).

Zheng, J., Robinson, W.R., Ehlen, T., Yu, M.C. and Dubeau. L., Distinction of low grade from high grade human ovarian carcinomas on the basis of losses of heterozygosity on chromosomes 3, 6, and 11 and HER-2/neu gene amplification. Cancer Res., 51, 4045-4051 (1991).

Zhou. D.J., Gonzalez-Cadavid, N., Ahuja, H., Battifora, H., MoOre, G.E. and Cline, M.J., A unique pattern of proto-oncogene abnormalities in ovarian adenocarcinomas. Cancer, 62, 1573-1576 (1988). 